\title{
Regulation of survival of rat pachytene spermatocytes by lactate supply from Sertoli cells
}

\author{
Nicolet H. P. M. Jutte, R. Jansen, J. A. Grootegoed, F. F. G. Rommerts, \\ O. P. F. Clausen* and H. J. van der Molen
}

Department of Biochemistry (Division of Chemical Endocrinology), Medical Faculty, Erasmus University, Rotterdam, The Netherlands and ${ }^{*}$ Institute of Forensic Medicine, Rikshospitalet, University of Oslo, Oslo, Norway

\begin{abstract}
Summary. During incubation of fragments of seminiferous tubules in the absence of glucose, pachytene spermatocytes and round spermatids died within $24 \mathrm{~h}$, while Sertoli cells were still viable. The germ cells survived for at least $72 \mathrm{~h}$ in seminiferous tubule fragments which were incubated in the presence of glucose. Lactate rather than glucose is essential for $\left[{ }^{3} \mathrm{H}\right]$ uridine incorporation and survival of isolated pachytene spermatocytes. However, if the spermatocytes were incubated in the presence of Sertoli cells, glucose maintained the incorporation of $\left[{ }^{3} \mathrm{H}\right]$ uridine into the germ cells. Sertoli cells secreted lactate in the presence of glucose and the lactate secretion was stimulated 2-4-fold by FSH. It is concluded that the activity and survival of pachytene spermatocytes in vitro can be regulated by the supply of lactate from Sertoli cells.
\end{abstract}

\section{Introduction}

In mammalian testes the walls of the seminiferous tubules are lined by Sertoli cells which are connected by tight junctions and thus form a barrier between the intratubular (adluminal) compartment and the extratubular environment (blood-testis barrier). The composition of the tubular fluid differs from the composition of lymph fluid and blood plasma (Setchell \& Waites, 1975). Early primary spermatocytes move across the blood-testis barrier and further germ cell development occurs in the adluminal compartment of the seminiferous tubules.

In the adluminal compartment Sertoli cells may control the composition of the fluid which surrounds the germ cells during development. Sertoli cells are target cells for FSH and testosterone (Fritz, 1978) and these hormones may therefore have an effect on the tubular micro-environment and thus on developing germ cells. Several compounds are known to be secreted by Sertoli cells, e.g. androgen binding protein (Fritz, Rommerts, Louis \& Dorrington, 1976), transferrin (Skinner \& Griswold, 1980), plasminogen activator (Lacroix \& Fritz, 1980), glycoproteins (Galdieri, Zani \& Stefanini, 1981), sulphoproteins (Elkington \& Fritz, 1980) and myo-inositol (Robinson \& Fritz, 1979). However, none of these compounds has been shown to affect germ cells. We have reported previously that RNA and protein synthesis and oxygen consumption of isolated spermatocytes and spermatids were stimulated by exogenous lactate (Jutte et al., $1981 \mathrm{a}$; Jutte, Grootegoed, Rommerts \& van der Molen, 1981b). These results have been confirmed by the observation that protein synthesis in round spermatids was stimulated by lactate (Nakamura, Hino, Yasumasu \& Kato, 1981). The capacity of isolated germ cells to use glucose as an energy source appears to be very low. Glucose, however, is essential for maintenance of spermatogenesis in vivo (Mancini, Penhos, Izquierdo \& Heinrich, 1960; Zysk, 
Bushway, Whistler \& Carlton, 1975). It is possible that the Sertoli cells convert glucose to a substrate which is used by germ cells, and we have investigated whether Sertoli cells can influence the activity and survival of germ cells via the secretion of lactate.

\section{Materials and Methods}

\section{Isolation of seminiferous tubules}

Testes from immature rats (Wistar, substrain R-Amsterdam, age 30-35 days, body weight 70-80 g) were decapsulated and treated with collagenase (CLS-I; Worthington, Freehold, New Jersey, U.S.A.; $10 \mathrm{mg}$ in $20 \mathrm{ml}$ ) in isolation medium (Jutte et al., 1981b) in a $100 \mathrm{ml}$ Erlenmeyer flask during $20 \mathrm{~min}$ at $32^{\circ} \mathrm{C}$ in a shaking waterbath (120 cycles per min). Tubules released by the enzyme treatment were washed three times by sedimentation at unit gravity in isolation medium. When used for culture, the tubules were also washed three times in incubation medium.

\section{Isolation of pachytene spermatocytes}

Isolated seminiferous tubules were treated for $15 \mathrm{~min}$ with isolation medium containing trypsin (TRL; Worthington; $10 \mathrm{mg}$ in $20 \mathrm{ml}$ ) and deoxyribonuclease (DN-Cl; Sigma, St Louis, Missouri, U.S.A.; $20 \mu \mathrm{g}$ in $20 \mathrm{ml}$ ), using the conditions described above, followed by addition of trypsin inhibitor (Sigma; $10 \mathrm{mg}$ in $20 \mathrm{ml}$ ) and bovine serum albumin (Sigma, fraction V; final concentration $0.5 \% \mathrm{w} / \mathrm{v}$ ). Subsequently, the tubules were dispersed during $3 \mathrm{~min}$ with a $1 \mathrm{ml}$ measuring pipette (i.d. $2.5 \mathrm{~mm}$ ) and the cell suspension was filtered through a nylon filter $(60 \mu \mathrm{m}$ pore size) to remove tubular fragments. A fraction of middle-late pachytene spermatocytes (72\% middle-late pachytene spermatocytes, $10 \%$ early primary spermatocytes, $14-17 \%$ other germ cells and unidentified cells, $1-4 \%$ somatic cells) was obtained by sedimentation of the cell suspension at unit gravity for $70 \mathrm{~min}$ at $22^{\circ} \mathrm{C}$ in a non-linear albumin gradient $(1-3.2 \% \mathrm{w} / \mathrm{v})$ (Grootegoed, Grollé-Hey, Rommerts \& van der Molen, 1977). The cells were washed three times in incubation medium without glucose before they were used for incubation.

\section{Isolation of Sertoli cells}

Sertoli cells were obtained as follows. Isolated seminiferous tubules were fragmented with a Dounce homogenizer (Fritz et al., 1976) and washed three times in incubation medium without glucose. The fragments were incubated without glucose for 1 day, followed by an incubation period of 4-5 days in the presence of $3.3 \mathrm{~mm}$-glucose and $1 \%(\mathrm{v} / \mathrm{v})$ fetal calf serum (Gibco, Glasgow, Scotland). Pachytene spermatocytes and more mature germ cells were killed during incubation in the absence of glucose and could easily be aspirated from these cultures.

In one series of experiments, as indicated in the text, Sertoli cells were isolated from testes of rats irradiated in utero with $150 \mathrm{rad}$ on Day 19 of gestation (Beaumont, 1960). The germ cell-depleted testes of these rats at 24-29 days of age were treated with collagenase, as described above, to obtain Sertoli cell aggregates which were fragmented with a Dounce homogenizer.

\section{Incubation conditions}

Cells or tubules were incubated in incubation medium (Jutte et al., $1981 \mathrm{~b}$ ) at $32^{\circ} \mathrm{C}$ under a humidified atmosphere of $5 \% \mathrm{CO}_{2}$ in air. Glucose and lactate concentrations are given in the 'Results'.

\section{Co-culture of Sertoli cells and pachytene spermatocytes}

Sertoli cell monolayers, cultured in 24-well tissue culture plates for 4-5 days, were washed once with medium without glucose and twice with medium containing the required glucose 
concentration. Subsequently, $0.25 \times 10^{6}$ pachytene spermatocytes were added to each well (2 $\mathrm{cm}^{2}$ ). After $30 \mathrm{~min}, 2 \mu \mathrm{Ci}\left[5{ }^{3} \mathrm{H}\right]$ uridine $/ \mathrm{ml}$ were added (final sp. act. $5 \mathrm{Ci} / \mathrm{mmol}$ ). After another $2 \mathrm{~h}$ the labelling was stopped with cold $0.9 \%(\mathrm{w} / \mathrm{v}) \mathrm{NaCl}$ containing $0.57 \mathrm{mM}$-uridine. The germ cells were removed from the Sertoli cell monolayer by gentle pipetting with a Pasteur pipette and the amount of $\left[{ }^{3} \mathrm{H}\right]$ uridine incorporated into RNA of the germ cells was determined by trichloroacetic acid precipitation of RNA on filters (Jutte et al., 1981b). Filters and precipitate were dissolved in $8 \mathrm{ml}$ Filtercount (Packard). Duplicate or triplicate incubations were performed for all conditions. Parallel incubations of Sertoli cells without germ cells were performed to estimate the concentration of lactate in the medium and the amount of cellular protein.

\section{Estimation of lactate and glucose}

Seminiferous tubules or Sertoli cells were preincubated for 1 day in $2 \mathrm{ml}$ incubation medium, unless stated otherwise. This medium contained $5 \mu \mathrm{g} \mathrm{FSH} / \mathrm{ml}$ (NIH-FSH-S 12, $1.25 \mathrm{U} / \mathrm{mg}$, was a gift from the Endocrinology Study Section, NIH, Bethesda, U.S.A.) and/or $200 \mathrm{ng}$ testosterone/ml or the solvents. Concentrated $(\times 100)$ stock solutions of FSH and testosterone were prepared in $0.9 \%(\mathrm{w} / \mathrm{v}) \mathrm{NaCl}$ containing $0.1 \%$ albumin (Povite, Amsterdam, Holland) and in $10 \%(\mathrm{v} / \mathrm{v})$ ethanol respectively.

The medium was removed and the cells were washed once with incubation medium. Subsequently, the cells were incubated for $24 \mathrm{~h}$ in $2 \mathrm{ml}$ fresh incubation medium containing FSH and/or testosterone and glucose $(0-6.6 \mathrm{~mm})$. The medium from the 2 nd day of culture was collected, centrifuged to remove unattached cells and kept frozen at $-20^{\circ} \mathrm{C}$ for not more than 1 week until lactate and/or glucose were determined. The attached and unattached cells were collected and lysed in $1 \mathrm{M}-\mathrm{NaOH}$ and protein was estimated (Lowry, Rosebrough, Farr \& Randall, 1951). Lactate was estimated enzymically, using lactate dehydrogenase (Hohorst, 1970). Glucose was estimated using enzymic conversion with hexokinase and glucose6-phosphate dehydrogenase (Schmidt, 1961). In all experiments single estimations of lactate and glucose were performed for duplicate incubations of Sertoli cells or seminiferous tubules.

\section{DNA flow cytometry}

Seminiferous tubules cultured for 1 day without or with glucose $(3.3 \mathrm{~mm})$, followed by 2 days of culture in the presence of glucose, were treated with $0.25 \%$ trypsin (Difco, Detroit, Michigan, U.S.A.; 1:250) in phosphate-buffered saline (Dulbecco \& Vogt, 1954) for $20 \mathrm{~min}$ at $37^{\circ} \mathrm{C}$. After dispersion by pipetting with a Pasteur pipette, a few drops of fetal calf serum (Gibco, Glasgow, Scotland) were added and the cells were washed in $0.9 \%(\mathrm{w} / \mathrm{v}) \mathrm{NaCl}$. The cells were fixed under continuous mixing by slow addition of cold ethanol $(96 \%, \mathrm{v} / \mathrm{v})$ to a final concentration of $70 \%(\mathrm{v} / \mathrm{v})$ ethanol. After $30 \mathrm{~min}$ at room temperature the cells were stored for several weeks at $4^{\circ} \mathrm{C}$. Then the suspensions were washed in $0.9 \%(\mathrm{w} / \mathrm{v}) \mathrm{NaCl}$ and incubated in $0.4 \%$ pepsin in $0.02 \mathrm{M}-\mathrm{HCl}$ at $37^{\circ} \mathrm{C}$ for $15 \mathrm{~min}$. The cells were cooled in ice, centrifuged and incubated for $30 \mathrm{~min}$ at room temperature in a mixture of ribonuclease A (Sigma type 1-A; 10 $\mathrm{mg} / \mathrm{l})$, ethidiumbromide (BDH, Poole, England; $10 \mathrm{mg} / \mathrm{l}$ ) and Nonidet P-40 (BDH; $300 \mu \mathrm{l} / \mathrm{l})$ (Vindeløv, 1977; Clausen \& Ảbyholm, 1980). The suspension was filtered through a nylon filter (70 $\mu \mathrm{m}$ pore size) and processed through an Ortho Cytofluorograph $50 \mathrm{H}$ (Ortho Instruments, Westwood, U.S.A.). The counting of the fluorescent nuclei was interrupted after the fluorescence in the highest peak had reached a maximal level. Therefore, the distribution of fluorescence over the different peaks was relative.

\section{Results}

Seminiferous tubules in culture produced lactate and the lactate production was dependent on the concentration of glucose in the medium (Text-fig. 1). No detectable change in glucose 


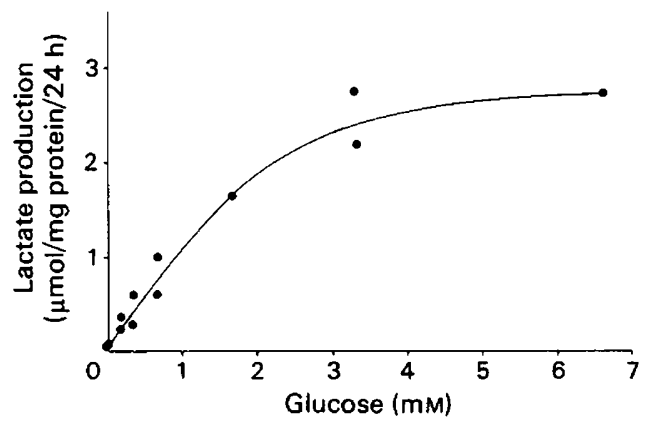

Text-fig.1. Effect of glucose on the lactate production by rat seminiferous tubules. Fragmented tubules were incubated for $48 \mathrm{~h}$ in $7.5 \mathrm{ml}$ medium containing different concentrations of glucose. Lactate was measured in the medium from the 2 nd day of incubation (24-48 h). Each point represents the mean of duplicate incubations. Two different cell preparations were used.

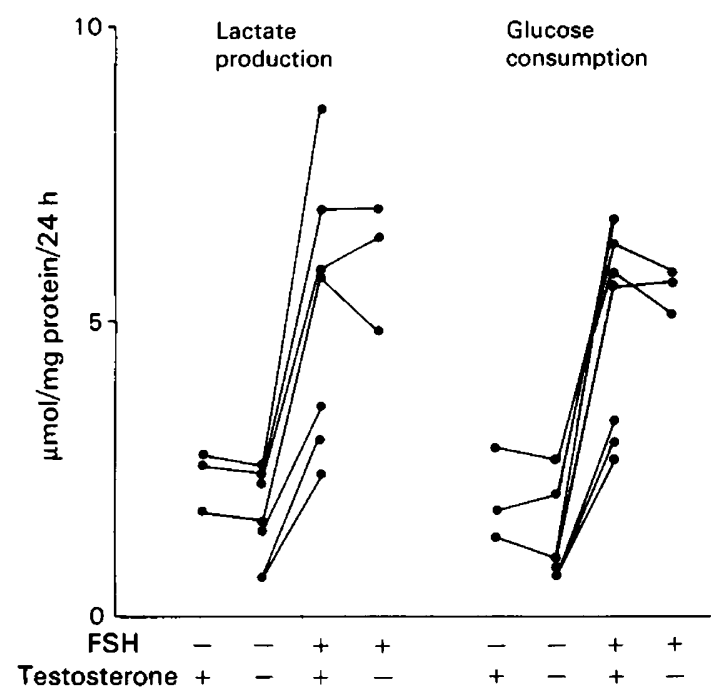

Text-fig. 2. Effect of FSH and testosterone on the lactate production and the glucose consumption of rat Sertoli cells. Sertoli cells obtained from irradiated rats were incubated in medium containing $3.3 \mathrm{~mm}$-glucose. FSH $(5 \mu \mathrm{g} / \mathrm{ml})$ and/or testosterone $(200 \mathrm{ng} / \mathrm{ml})$ were present during the incubation from 0 to $48 \mathrm{~h}$. Glucose and lactate concentrations were measured in media collected during $24 \mathrm{~h}$ culture $(24-48 \mathrm{~h})$. Results obtained with the same cell preparation are connected.

concentration occurred during incubation under these conditions. The lactate secretion by seminiferous tubule fragments from 27-day-old rats was stimulated 3 -fold by FSH. Because germ cells may metabolize part of the lactate secreted in seminiferous tubule cultures, we have also studied pure Sertoli cells isolated from irradiated rats. Like seminiferous tubule fragments from intact rats these pure Sertoli cells were able to convert glucose to lactate and the lactate secretion and glucose consumption were stimulated 2-4-fold by a mixture of FSH and testosterone (Text-fig. 2). This stimulation appeared to be caused by FSH under these conditions (Text-fig. 2). 


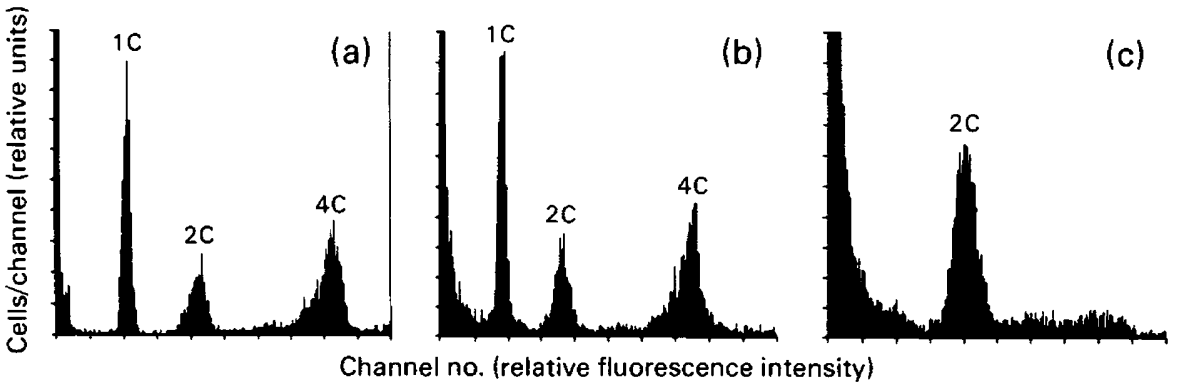

Text-fig. 3. DNA flow cytometric analysis of rat seminiferous tubules cultured for 1 day with or without glucose. Isolated seminiferous tubules were processed for DNA flow cytometric measurements as described in 'Materials and Methods' section. (a) Freshly isolated; (b) incubated for 3 days in the presence of glucose $(3.3 \mathrm{~mm})$; (c) incubated for 1 day in the absence of glucose followed by 2 days in the presence of glucose $(3.3 \mathrm{~mm})$. Nuclei of primary spermatocytes (4C), spermatids (1C), somatic cells, secondary spermatocytes and spermatogonia (2C) showed different fluorescence after staining of their DNA with ethidium bromide.

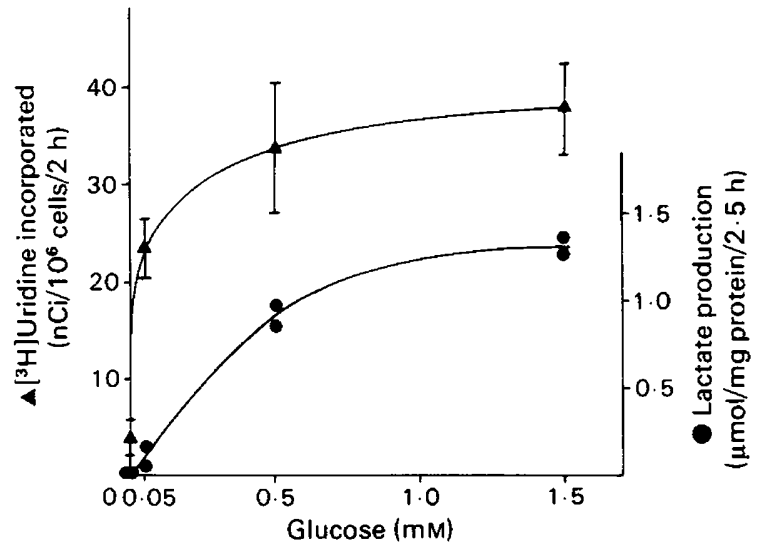

Text-fig. 4. The effect of glucose on the incorporation of $\left[{ }^{3} \mathrm{H}\right]$ uridine into rat spermatocytes, co-cultured with Sertoli cells. Pachytene spermatocytes $\left(0.25 \times 10^{6}\right)$ were labelled with $\left[5-{ }^{3} \mathrm{H}\right]$ uridine during $2 \mathrm{~h}$ of co-culture with Sertoli cells. The radioactivity incorporations into the spermatocytes are given as means \pm s.d., obtained with 3 different germ cell and Sertoli cell preparations. The amount of lactate estimated in parallel incubations of Sertoli cells is given for 2 different cell preparations.

It was shown by phase-contrast microscopy and by cytofluorometric measurements that spermatids and pachytene spermatocytes survived when fragments of seminiferous tubules were incubated for 3 days in the presence of glucose $(3.3 \mathrm{~mm}$ ) (Text-figs $3 \mathrm{a}, \mathrm{b}$ ). However, when seminiferous tubules were incubated without glucose for 1 day, spermatids and spermatocytes were absent (Text-fig. 3c). The Sertoli cells in these tubule cultures survived 1 day of glucose depletion, because after addition of glucose $(3.3 \mathrm{~mm})$ on the 2 nd day of incubation, the Sertoli cells migrated normally, incorporated leucine (as judged by radioautography) and produced $0.96 \pm 0.55 \mu \mathrm{mol}$ lactate $/ 24 \mathrm{~h}$ (compared to controls incubated with glucose, which produced $0.85 \pm 0.37 \mu \mathrm{mol}$ lactate $/ 24 \mathrm{~h}$ ). Previously we observed that isolated pachytene spermatocytes, incubated in the presence of glucose, did not incorporate significant amounts of $\left[{ }^{3} \mathrm{H}\right.$ |uridine and $\left[{ }^{14} \mathrm{C}\right]$ leucine (Jutte et al., 1981b). However, the incorporation of $\left[{ }^{3} \mathrm{H}\right]$ uridine into RNA of isolated spermatocytes incubated in contact with Sertoli cells increased with increasing glucose concentrations (Text-fig. 4). In the absence of glucose, the activity of spermatocytes in 
these co-cultures was minimal; maximal activity was reached only in the presence of glucose concentrations greater than $0.5 \mathrm{mM}$. Lactate production by the Sertoli cells under these conditions was also dependent on the glucose concentration (Text-fig. 4).

Isolated spermatocytes incubated in the presence of $6 \mathrm{mM}$-DL-lactate and $1.5 \mathrm{mM}$-glucose incorporated $22.7 \pm 4.2 \mathrm{nCi}\left[{ }^{3} \mathrm{H}\right]$ uridine $\left(10^{6}\right.$ cells $\left./ 2 \mathrm{~h}\right)$. Spermatocytes incubated on top of Sertoli cells in the presence of $1.5 \mathrm{~mm}$-glucose incorporated $23 \cdot 1 \pm 8 \cdot 3 \mathrm{nCi}\left[{ }^{3} \mathrm{H}\right]$ uridine $\left(10^{6}\right.$ cells $/ 2 \mathrm{~h}$ ) (means \pm s.d. of 3 different cell preparations). Therefore, the $\left|{ }^{3} \mathrm{H}\right|$ uridine incorporation in spermatocytes appeared to be maintained both in the presence of Sertoli cells plus glucose and in the presence of lactate.

\section{Discussion}

Isolated pachytene spermatocytes do not survive in the presence of glucose (Jutte et al., 1981b). The present results, however, indicate that RNA synthesis and the integrity of pachytene spermatocytes in cultures of seminiferous tubules and in co-cultures of isolated germ cells and Sertoli cells were maintained by exogenous glucose (Text-figs 3 and 4). When glucose was omitted from these incubations, the pachytene spermatocytes did not survive (Text-fig. 3c). Lactate is known to be essential for survival of germ cells (Jutte et al., 1981b) and the present results indicate that this substrate maintained isolated pachytene spermatocytes as well as did Sertoli cells. Lactate was secreted by the Sertoli cells and this secretion was stimulated by hormones and glucose (Text-figs 1 and 2). These observations support the idea that the activity and survival of pachytene spermatocytes is regulated by Sertoli cells via conversion of glucose to lactate.

Most studies on metabolic pathways in the testis have been performed with mixed cell populations and little is known about metabolic activities in different cell types. It has been suggested that somatic cells in the testis are mainly dependent on lipids for the provision of energy (Free, 1970). We observed that Sertoli cells survived an incubation of $24 \mathrm{~h}$ without glucose; Sertoli cells may use lipids under these conditions. Study of the metabolism of glucose by cultures of pure Sertoli cells showed that maximally $2.9 \%$ of the glucose utilized was converted to carbon dioxide and $95.8 \%$ was converted to anionic compounds, mostly to lactate (Robinson \& Fritz, 1981). These observations demonstrate the enormous capacity of Sertoli cells to convert glucose into lactate. In contrast to our observations, Robinson \& Fritz (1981) did not observe a stimulatory effect of hormones on lactate production by Sertoli cells. This may be caused by differences in the preparation of the Sertoli cells. The concentration of lactate in tubular fluid in vivo is not known, but might be comparable to the concentration of lactate in rete testis fluid $(0.65 \mathrm{~mm}$ in rams and $0.74 \mathrm{~mm}$ in bulls), which is half the concentration present in blood plasma (Setchell, Scott, Voglmayr \& Waites, 1969). Glucose appears to be available in the testis because its concentration in the testicular lymph of the rat is as high as the concentration in blood plasma ( $\pm 3 \mathrm{~mm}$ ) (Setchell \& Waites, 1975). This does not imply, however, that the Sertoli cells are directly exposed to these concentrations, because at least one other cell type (myoid cells) is interposed between the Sertoli cells and the lymph.

The glucose uptake and/or the glycolysis in isolated germ cells appears to be defective. Lactate oxidation via the Krebs' cycle could supply energy for metabolic activities. Germ cells may be able to maintain an aerobic metabolism, because it has been shown that the oxygen tension in seminiferous tubules is as high as the tension in testis interstitial tissue (Free, Schluntz \& Jaffe, 1976). An extreme dependence of germ cells on the activity of the Krebs' cycle is illustrated by in-vivo experiments with rats which were fed inhibitors of the Krebs' cycle. While other tissues were not affected, spermatocytes and spermatids died. This degeneration is probably not caused by a direct effect of the inhibitors on Sertoli cells, because these cells remained in the tubules and were able to support a restored spermatogenesis (Paul, Paul, 
Kopko, Bender \& Everett, 1953; Novi, 1968; Steinberger \& Sud, 1970; Sullivan, Smith \& Garman, 1979).

In different stages of germ cell development, a different dependence of germ cells on carbohydrate substrates appears to exist. Round spermatids and pachytene spermatocytes are dependent on a supply of lactate (Jutte et al., 1981b), whereas ejaculated spermatozoa can use glucose or fructose as substrates (Voglmayr, 1975). Therefore, following a stage of dependence on lactate, germ cells may become independent of lactate during or after spermatid elongation.

The present results indicate that lactate from Sertoli cells influences the survival of pachytene spermatocytes and that the lactate production is increased by hormones. Lactate could therefore be an important intermediate for the regulation of the survival of pachytene spermatocytes and round spermatids by hormones.

We thank Dr B. G. Blijenberg and the Central Clinical-Chemical Laboratory of the Dijkzigt Hospital for assistance with the estimations of glucose and Miss W. Bakhuizen for help in the preparation of this manuscript. This work was supported in part by the Dutch Foundation for Medical Research (FUNGO) and NATO-grant 180.80.

\section{References}

Beaumont, H.M. (1960) Changes in the radiosensitivity of the testis during foetal development. Int. J. Radiat. Biol. 2, 247-256.

Clausen, O.P.F. \& Abyholm, T. (1980) Deoxyribonucleic acid flow cytometry of germ cells in the investigation of male infertility. Fert. Steril. 34, 369-374.

Dulbecco, R. \& Vogt, M. (1954) Plaque formation and isolation of pure lines with poliomyelitis viruses. $J$. exp. Med. 99, 167-182.

Elkington, J.S.H. \& Fritz, I.B. (1980) Regulation of sulfoprotein synthesis by rat Sertoli cells in culture. Endocrinology 107, 970-976.

Free, M.J. (1970) Carbohydrate metabolism in the testis. In The Testis, Vol. II, pp. 125-192. Eds A. D. Johnson, W. R. Gomes \& N. L. VanDemark. Academic Press, New York.

Free, M.J., Schluntz, G.A. \& Jaffe, R.A. (1976) Respiratory gas tensions in tissues and fluids of the male reproductive tract. Biol. Reprod. 14, 481-488.

Fritz, I.B. (1978) Sites of actions of androgens and follicle-stimulating hormone on cells of the seminiferous tubule. In Biochemical Actions of Hormones, Vol. 5, pp. 249-281. Ed. G. Litwack. Academic Press, New York.

Fritz, I.B., Rommerts, F.F.G., Louis, B.G. \& Dorrington, J.H. (1976) Regulation by FSH and dibutyryl cyclic AMP of the formation of androgenbinding protein in Sertoli cell-enriched cultures. $J$. Reprod. Fert. 46, 17-24.

Galdieri, M., Zani, B. \& Stefanini, M. (1981) Effect of the association with germ cells on the secretory activities of Sertoli cells in in-vitro cultures. In Oligozoöspermia. Eds G. Frajese, E. S. E. Hafez, A. Fabbrini \& C. Conti. Raven Press, New York (In press).

Grootegoed, J.A., Grollé-Hey, A.H., Rommerts, F.F.G. \& van der Molen, H.J. (1977) Ribonucleic acid synthesis in vitro in primary spermatocytes isolated from rat testis. Biochem. J. 168, 23-31.
Hohorst, H.J. (1970) L-(+)-Lactat, Bestimmung mit Lactat-Dehydrogenase und NAD. In Methoden der Enzymatische Analyse, 2nd edn, part II, pp. 14251429. Ed. H. U. Bergmeyer. Verlag Chemie GmbH, Weinheim.

Jutte, N.H.P.M., Koolen, L.M., Jansen, R., Grootegoed, J.A., Rommerts, F.F.G. \& van der Molen, H.J. (1981a) Lactate essential for biochemical activities in isolated germinal cells. Int. J. Androl., Suppl. 3, 59, Abstr.

Jutte, N.H.P.M., Grootegoed, J.A., Rommerts, F.F.G. \& van der Molen, H.J. (1981b) Exogenous lactate is essential for metabolic activities in isolated rat spermatocytes and spermatids. J. Reprod. Fert. 62, $399-405$.

Lacroix, M. \& Fritz, I.B. (1980) Characterization of a plasminogen activator secreted by rat Sertoli cells in culture. J. Cell Biol. 87, 152a.

Lowry, O.H., Rosebrough, N.H., Farr, A.L. \& Randall, R.J. (1951) Protein measurement with the Folin phenol reagent. J. biol. Chem. 193, 265-275.

Mancini, R.E., Penhos, J.C., Izquierdo, I.A. \& Heinrich, J.J. (1960) Effects of acute hypoglycemia on rat testis. Proc. Soc. exp. Biol. Med. 104, 699-702.

Nakamura, M., Hino, A., Yasumasu, I. \& Kato, J. (1981) Stimulation of protein synthesis in round spermatids from rat testes by lactate. J. Biochem. 89 , 1309-1315.

Novi, A.M. (1968) Injury of primary spermatocytes during the meiotic prophase and temporary arrest of spermatogenesis induced by fluoroacetamide in the rat. Virchows Archiv. Abt Q. Zellpath. 1, 346-364.

Paul, H.E., Paul, M.F., Kopko, F., Bender, R.C. \& Everett, G. (1953) Carbohydrate metabolism studies on the testis of rats fed certain nitrofurans. Endocrinology 53, 585-592.

Robinson, R. \& Fritz, I.B. (1979) Myoinositol biosynthesis by Sertoli cells, and levels of myoinositol biosynthetic enzymes in testis and epididymis. Can. J. Biochem. 57, 962-967. 
Robinson, R. \& Fritz, I.B. (1981) Metabolism of glucose by Sertoli cells in culture. Biol. Reprod. 24, 10321041.

Schmidt, F.H. (1961) Die enzymatische Bestimmung von Glucose und Fructose nebeneinander. Klin. Wschr. 39, 1244-1247.

Setchell, B.P. \& Waites, G.M.H. (1975) The blood-testis barrier. In Handbook of Physiology, section 7, vol. V, chapter 7, pp. 143-172. Eds R. O. Greep, E. B. Astwood, D. W. Hamilton \& S. R. Geiger. Am. Physiol. Soc., Washington, D.C.

Setchell, B.P., Scott, T.W., Voglmayr, J.K. \& Waites, G.M.H. (1969) Characteristics of testicular spermatozoa and the fluid which transports them into the epididymis. Biol. Reprod. 1, 40-66.

Skinner, M.K. \& Griswold, M.D. (1980) Sertoli cells synthesize and secrete transferrin-like protein. J. biol. Chem. 255, 9523-9525.

Steinberger, E. \& Sud, B.N. (1970) Specific effect of fluoroacetamide on spermiogenesis. Biol. Reprod. 2 , 369-375.

Sullivan, J.L., Smith, F.A. \& Garman, R.H. (1979) Effects of fluoroacetate on the testis of the rat. $J$. Reprod. Fert. 56, 201-207.

Vindeløv, L.L. (1977) Flow microfluorometric analysis of nuclear DNA in cells from solid tumours and cell suspensions. Vitrchows Arch, B Cell Path. 24, 227242.

Voglmayr, J.K. (1975) Metabolic changes in spermatozoa during epididymal transit. In Handbook of Physiology, section 7, vol. V, chapter 21, pp. 437-451. Eds R. O. Greep, E. B. Astwood, D. W. Hamilton \& S. R. Geiger. Am. Physiol. Soc. Washington, D.C.

Zysk, J.R., Bushway, A.A., Whistler, R.L. \& Cariton, W.W. (1975) Temporary sterility produced in male mice by 5-thio-D-glucose. J. Reprod. Fert. 45, 69-72.

Received 6 October 1981 